\title{
Recalibrating the Conception of Codification in the Changing Landscape of International Law
}

\author{
Keun-Gwan Lee
}

Introduction

In a book that looks back on the first 5 o years of the International Law Commission, a general evaluation was given as follows:

The extent to which, at the end of the twentieth century, international law is a more mature system of law and its practitioners can regard their subject with self-confidence in its worth is very largely due to the contribution made over the first fifty years of its existence by the International Law Commission. ${ }^{1}$

A decade earlier, a no less enthusiastic assessment ("the most remarkable achievements yet known in the field of the progressive development and codification of international law") was made by another eminent authority. ${ }^{2}$ On the seventieth anniversary of the establishment of the International Law Commission, one can readily agree to these opinions. Having said this, it is also true that one hears of "a deep-seated uncertainty about the contemporary role of the Commission". ${ }^{3}$ About a decade ago, a former member of the Commission wrote an article entitled "The International Law Commission - An Outdated Institution?". ${ }^{4}$

In this contribution, written on the occasion of the seventieth anniversary of the Commission, I will try to address some questions concerning the proper role and status of the Commission and venture a few suggestions.

1 Arthur Watts, The International Law Commission 1949-1998, vol 1 (OU P 1999) 20.

2 José Sette-Camara, 'The International Law Commission: Discourse on Method' in International Law at the Time of its Codification: Essays in Honour of Roberto Ago, vol 1 (Giuffrè 1987) 467.

3 David McRae, "The Interrelationship of Codification and Progressive Development in the Work of the International Law Commission' (2013) 111 JILD 75, 76.

4 Christian Tomuschat, 'The International Law Commission - An Outdated Institution?' (2006) 49 GYIL 77. 
The main function of the International Law Commission, which is composed of individual experts, is "the promotion of progressive development of international law and its codification". 5 Since the idea of codification of international law is a concept with a long historical pedigree, I will start by retracing the evolution of the concept from the late 18th century until the end of the Second World War (II). This is not done only for historical interest; the overview will show that some common themes have shaped conceptions of codification of international law for more than two centuries.

I will go on to briefly analyze the debate which took place at the first meetings of the inaugural session of the International Law Commission (III). This will demonstrate that there existed much divergence among the members of the Commission on the conception of codification and how to approach it. In the next section, I will introduce a taxonomy of the codification of international law as discussed and conducted by the Commission (IV). In addition to an explanatory function, the taxonomy will be instrumental in venturing some suggestions for the future role and function of the Commission, which I will attempt at the next section (v). A few concluding remarks will follow (VI).

In this section, I will discuss how the idea of codification of international law has evolved since the late 18th century. As a concept that has been around for more than two centuries, it is not surprising that it would experience a certain evolution. At the same time, we can find some themes undergirding most conceptions of codification of international law.

Jeremy Bentham is generally regarded as having initiated the idea of codification of international law. ${ }^{6}$ In his Principles of International Law, he started his discussion by raising the following hypothetical question: "If a citizen of the world had to prepare an universal international code, what would he propose to himself as his object?"7 In the same essay, he offered a list of seven

Article 1(1) of the statute of the ILC, UNGA Res 174(II) (21 November 1947) as amended by Unga Res 485(v) (12 December 1950); Unga Res 984(x) (3 December 1955); Unga Res 985 (x) (3 December 1955) and UngA Res 36/39 (18 November 1981).

6 For a detailed discussion of Bentham's idea on the codification of international law, see Ernest Nys, 'The Codification of International Law' (1911) 5 AJIL 871, 876.

7 Jeremy Bentham, The Works of Jeremy Bentham, vol 2 (William Tait 1843) 537. The manuscripts of Principles of International Law bear dates from 1786 to 1789. In Essay 1 entitled 
"causes of offences de bonne foi [among sovereigns], and of wars" and went to propose "Means of Prevention" as follows:

1. Homologation of unwritten laws which are considered as established by custom.

2. New conventions - new international laws to be made upon all points which remain unascertained; that is to say, upon the greater number of points in which the interests of two states are capable of collision. ${ }^{8}$

What is important for our purposes is the fact that Bentham, who has been called "the arch-priest of codification", ${ }^{9}$ put forth the distinction between the "homologation" of existing custom and the regulation of "unascertained" questions by treaty-making. ${ }^{10}$ This distinction bears striking similarities to that introduced by article 15 of the Commission's statute, that is, the distinction between codification and progressive development of international law. ${ }^{11}$

"Objects of International Law", Bentham provided an answer based on his utilitarian thinking: "the greatest happiness of all nations taken together" or "the most extended welfare of all the nations on the earth". Ibid 538 .

8 Ibid 540. Bentham adds the third means of prevention as follows: "Perfecting the style of the laws of all kinds, whether internal or international. How many wars have there been, which have had for their principal, or even their only cause, no more noble origin than the negligence or inability of a lawyer or a geometrician!".

9 This was the expression used by the "Sub-Committee upon the History and Status of Codification" formed under the "Committee of the American Society of International Law on the Codification of the Principles of Justice in Times of Peace between Nations, appointed under the Resolution of the Society of April 24, 1909". See the Committee's preliminary report (1910) 4 ASILPROC at Its Annual Meeting (1907-1917) $197,208$.

10 For Bentham's later writings on codification of international law, see Jeremy Bentham, Traités de Legislation Civile et Pénale, vol 3 ( $3^{\text {rd }}$ edn, Rey et Garavier 1830). The first edition of this book was published in 1802 . The three chapters mentioned in volume 3 of the book are included in the part dealing with "Vue Générale d'un Corps Complet de Législation". See also Bentham's unpublished letters addressed to Jabez Henry from July 1827 and January 1830; for a succinct discussion of these letters, see Ernst Nys, 'Notes inédites de Bentham sur le droit international' (1885) 1(2) LQR 225.

11 Article 15 of the Commission's statute provides as follows: "In the following articles, the expression 'progressive development of international law' is used for convenience as meaning the preparation of draft conventions on subjects which have not yet been regulated by international law or in regard to which the law has not yet been sufficiently developed in the practice of States. Similarly, the expression 'codification of international law' is used for convenience as meaning the more precise formulation and systematization of rules of international law in fields where there already has been extensive State practice, precedent and doctrine." 
Bentham did not regard the codification as a purely academic or utopian exercise. ${ }^{12}$ He suggested "l'idée de la redaction d'un corps de droit international par un congrès qui serait composé d'un délégué par Etat civilisé". ${ }^{13}$ He proposed a confederation of States which "has for its objects, or say ends, in view the preservation, not only of peace (in the sense in which by peace is meant absence of war), but of mutual good-will and consequent mutual good offices between all the several members of this confederation". ${ }^{14}$ He envisaged this confederation to be equipped "with the Code of International Law approved, adopted and sanctioned by it".15 Thus, Bentham was well aware of the dual nature of codification of international law both as the work of "a world citizen [called on] to prepare an universal code of international law" and as requiring sovereign approval to be granted on this work to achieve normative effectiveness. This dual nature mirrors the tension between, on the one hand, the International Law Commission as a body of independent experts, and, on the other, States concerned about their "legislative monopoly" in international law. To borrow the expression employed by an international lawyer well versed with the work of the International Law Commission, Bentham was keenly cognizant of the "diplomatic character" inherent in the codification of international law. ${ }^{16}$

12 In his 1924 article, Baker observed that "Jeremy Bentham first proposed the codification of international law. The conception of his fertile, logical, but not wholly practical mind, was not that of a code of the existing law of nations, but of a new Utopian code which would create a legal foundation for eternal peace." PJ Baker, "The Codification of International Law' (1924) 5 BYIL 38 . That Bentham was far from being a utopian daydreamer is shown by, among others, the following argument of his: "Under a system of international law the imperative could not be exercised by any authority: not even by the international congress. The admission of the faculty of issuing imperative decrees with power for giving execution and effect to them, would have the effect of an attempt to establish an Universal Republic, inconsistent with the Sovereignty of the several Sovereigns within their respective dominations." As quoted in Nys (n 6) 879. See also Nys (n 10) 229 .

13 Nys (n 10) 227-228.

14 Article 6 of Bentham's proposed code, as quoted in Nys (n 10) 227-228. One can also find the text of the code as an appendix to the preliminary report of the Committee of the American Society of International Law on the Codification of the Principles of Justice in Times of Peace between Nations (n 9) 223-224.

15 Ibid.

16 Carl-August Fleischhauer, 'The United Nations and the Progressive Development and Codification of International Law' (1985) 25 IJIL 1, 2. For a detailed discussion of the political character of the Commission's work, see BG Ramcharan, The International Law Commission: Its Approach to the Codification and Progressive Development of International Law (Martinus Nijhoff 1977) ch 5 . 
This short analysis shows that the key problems often discussed in connection with the International Law Commission are already found in Bentham's ideas on the codification of international law, if not exactly in the same shape or form. This observation attests to the tremendous fecundity of Bentham's mind. At the same time, the afore-mentioned dual nature of codification of international law is inevitable given that the codification of international law is ultimately geared towards the practical goal of attaining peace in international relations.

As is well known, Bentham's idea was further developed by a series of efforts at what is often termed "private codification"17 or "private attempts at codification". ${ }^{18}$ These attempts were made by academic lawyers, working both individually and in learned societies such as the Institut de Droit international or the International Law Association, which was originally called "the International Association for the Reform and Codification of the Law of Nations". In connection with the private attempts at codification, one often encounters names such as Abbé Grégoire, ${ }^{19}$ Alfons von Domin-Petruschévecz, ${ }^{20}$ Francis Lieber, Johann Caspar Bluntschli, David Dudley Field, ${ }^{21}$ Pasquale Fiore, ${ }^{22}$ E. Duplessix ${ }^{23}$ and Jerome Internoscia. ${ }^{24}$

17 In French, this is also known as "la codificadftion privée ou scientique". See, for instance, Georges Abi-Saab, 'La Commission du Droit International, la Codification et le Processus de Formation du Droit International' in United Nations (ed), Making Better International Law: The International Law Commission at 50, Proceedings of the United Nations Colloquium on Progressive Development and Codification of International Law (United Nations 1998) 188.

18 For a detailed discussion of various private attempts at codification, see RP Dhokalia, The Codification of Public International Law (Manchester University Press 1970) 37-75. See also United Nations, 'Note on the Private Codification of Public International Law' (1947) 41(4) AJIL (Supplement: Official Documents) 138-147; Hersch Lauterpacht, International Law: Collected Papers, Volume 1 (The General Works) (CuP 1970) 98-100.

19 The text of his "Declaration of the Law of Nations" appears as an appendix to the preliminary report of the Committee of the American Society of International Law on the Codification of the Principles of Justice in Times of Peace between Nations (n 9) 226-227.

$20 \quad$ Précis d'un Code du Droit International (Brockhaus 1861).

21 Draft Outlines of a Code of International Law (Diossy \& Company 1872). For a detailed discussion of Field's work on the codification of international law, see Herbert W Briggs, 'David Dudley Field and the Codification of International Law' in Institut de Droit international (ed), Livre du Centenaire, 1873-1973: Évolution et Perspectives du Droit International (S. Karger 1973) 67-73.

22 Il Diritto Internazionale Codificato e la Sua Sanzione Giuridica (Unione Tipografico-Editrice 189o). For the English translation from the fifth edition of this book, see Edwin M Borchard, International Law Codified and its Legal Sanction (Baker, Voorhis and Company 1918).

23 La Loi des Nations; Projet d'Institution d'une Autorité Nationale, Législative, Administrative, Judiciaire. Projet de Code de Droit International Public (L. Larose \& L. Tenin 19o6). New Code of International Law (The International Code Company of New York 1910). 
According to an assessment by Professor Rosenne, these private efforts undertaken during the 19th century "made little impression on Governments". 25 Nevertheless, scholars persisted. One of the best-known attempts at the codification of international law, that is, Bluntschli's Das moderne Völkerrecht der civilisirten Staten als Rechtsbuch dargestellt (1868) was written on stimulus provided by the resounding success of the codification of the law of war on land by Lieber. In 1863, Lieber's Instructions for the Government of the Armies of the United States in the Field, revised by a board of officers and approved by the President of the United States, was published by the United States War Department as General Order No. 10o. Bluntschli welcomed this document as "a first codification of the law of wars on land". ${ }^{26} \mathrm{He}$ was acutely aware of the difference between private and official codification. He stated that "[s]ince the academic codes (Rechtsbücher) are the product of private individuals, whereas the legal codes (Gesetzbücher) are promulgated by State authority, the former cannot claim the binding authority that secures the duty of obedience to the statutes."27

Some attempts at private codification were undertaken with the aim of ultimate approval by official authorities (and the resultant acquisition of binding legal authority). The Institut de Droit international unanimously adopted the Oxford Manual on the Laws of War on Land on 9 September 1880. ${ }^{28}$ In its preamble, the Institut tried to reassure "military men", who were the immediate addressees of the norms contained in the Manual, by emphasizing that the document was an exercise in "consolidating codification".29 It also made clear that it did not propose an international treaty, but "a 'Manual' suitable as the basis for national legislation in each State". ${ }^{30}$ After the adoption of this Manual, Bluntschli sent a copy of it to Marshal Moltke of Germany, asking for the recognition, or endorsement, of it. ${ }^{31}$ In this way, Bluntschli wanted to replicate the success of the Lieber Code in Europe. ${ }^{32}$

25 Shabtai Rosenne, 'The International Law Commission, 1949 - 1959' (1960) 36 BYIL 104, 106.

26 Johann Caspar Bluntschli, Das moderne Völkerrecht der civilisirten Staten als Rechtsbuch dargestellt (C.H. Beck 1868) 5 (translation by the author).

27 Ibid 7 (translation by the author).

28 IDI, 'Les lois de la guerre sur terre. Manuel publié par l'Institut de droit international.' (Oxford 1881-1882) 5 AnnIDI 157.

29 "The Institute has not sought innovations in drawing up the 'Manual'; it has contented itself with stating clearly and codifying the accepted ideas of our ages so far as this has appeared allowable and practicable." Ibid preamble.

30 Ibid (translation by author).

31 Johann Caspar Bluntschli, Denkwürdiges aus Meinem Leben, vol III (C.H. Beck 1884) 471. According to Moltke, Bluntschli "wünsch[te] [s]eine Anerkennung desselben".

32 In the Introduction to his 1868 Rechtsbuch, Bluntschli urged the European States "not to lag behind the example of the American States any longer" in respect of the laws of 
The project of codification no longer remained in the private and academic sphere as it was taken up by the governments. A long list of conferences, usually starting with the 1815 Congress of Vienna through the 1856 Congress of Paris leading up to the 1899 and 1907 Hague Peace Conferences, is often presented as exemplifying "official efforts at codification" 33 of international law. Whether the instruments adopted at these conferences can be regarded as the result of "conscious and sustained" attempts at official codification or represent "to a large extent a secondary development, accepted universally, of a contractual arrangement originally destined to remove serious sources of international friction" ${ }^{34}$ is open to debate. ${ }^{35}$

war on land, (n 26) 6. The correspondence between Bluntschli and Moltke is introduced in the following books. Jules Guelle, La Guerre Continentale et les Personnes (Librairie Militaire de J. Dumaine 1881) v-vii ; Martti Koskenniemi, The Gentle Civilizer of Nations (CUP 2010) 84-85.

Another champion of the codification of international law, David Dudley Field, is a case in point. In the preface to Draft Outlines of an International Code, he stated in no uncertain terms that "[his] scheme embraced not only a codification of existing rules of international law, but the suggestion of such modifications and improvements as the more matured civilizations of the present age should seem to require." Also, the very first article of his International Code is titled "adopting clause", according to which "[t]he following rules are established and declared by the nations assenting hereto, as an International Code ..." Field (n 21) 1.

33 This expression is used in chapter 3 of Dhokalia's book (n 18$)$.

34 Rosenne (n 25) 107.

35 For the latter view, see Rosenne (n 25) 107. In this connection, he referred to the 1815 Vienna Regulation and the 1856 Declaration of Paris. One can raise the question of whether Rosenne's assessment applies to other instruments, in particular those adopted at the 1899 and 1907 Hague Conferences. The 1899 Conference was "unusually for the $19^{\text {th }}$ century, whose end [it] marked, ... called not for the great European powers to resolve a specific war or conflict or to divide territory or other spoils of war." Betsy Baker, 'Hague Peace Conferences (1899 and 1907)' Max Planck Encyclopedia of Public International Law (November 2009) <opil.ouplaw.com/home/EPIL>, para 1. In a 1904 telegram concerning the convocation of the Second Hague Conference, John Hay, the then Secretary of State of the United States of America, stated that in the First Hague Conference the subjects such as "the rights and duties of neutrals, the inviolability of private property in naval warfare, and the bombardment of ports, towns, and villages by a naval force" had been relegated to a future conference. James Brown Scott (ed), The Conventions and Declarations of 1899 and 1907 (OUP 1915) xxii. It is true that the adoption of some instruments was prompted by specific incidents or disputes. The 1907 Convention Relative to the Opening of Hostilities, the conclusion of which was precipitated by the concern raised about Japan's surprise attack on a Russian ship at Port Arthur in early 1904, is a prime example. However, this does not detract from the codificatory character of the Hague Conferences. For a discussion of "the juridicalization of the world in the $19^{\text {th }}$ century" (die Verrechtlichung der Welt im 19. Jahrhundert), see Marcus M. Payk, Frieden durch Recht? Der Aufstieg des modernen Völkerrechts und der Friedensschluss nach dem Ersten Weltkrieg (De Gruyter 2018) 29-45. 
What is beyond doubt is that international relations were progressively "juridicalized" since the second half of the 19th century and that this trend was strengthened with the establishment of the League of Nations. In its preamble, the Covenant of the League of Nations declared the commitment of the High Contracting Parties to, among others, "the firm establishment of understandings of international law as the actual rule of conduct among Governments" and "the maintenance of justice and a scrupulous respect for all treaty obligations in the dealings of organized peoples with one another". ${ }^{36}$ It is not surprising that many commentators believed that the launch of the League of Nations had brought about "a remarkably rapid growth of the International Law of Peace.."37 They also pinned much hope on the prospect of "preparation of the conventions through a permanent international organization representing the whole society of States". 38

In the specific context of codification of international law, it was the first resolution of the Advisory Committee of Jurists ("assembled at the Hague, to prepare the constituent Statute of a Permanent Court of International Justice" $)^{39}$ which gave an impetus to the 1930 Hague Codification Conference. At the close of the proceedings that extended from 16 June to 24 July 1920, the Committee recommended the calling of a new inter-state conference "to carry on the work of the two first Conferences at the Hague". ${ }^{40}$ The objectives of this "successor conference" as proposed by the Committee clearly carried the dual character of the codificatory endeavour. ${ }^{41}$ The Committee also recommended that "the new Conference should be called the Conference for the advancement of international law".42

$36 \quad$ Adopted 28 April 1919, entered into force 10 January 1920.

37 Baker (n 12) 59. See also Manley O Hudson, International Legislation, vol I (Carnegie Endowment for International Peace 1931) xxxvii ("The future of international legislation will probably be very much influenced by the Assembly of the League of Nations"). He regarded the Assembly as "the nearest approach made to date to an international legislature". Ibid. Judge Guerrero opined in a similar vein that "[n] ous voici parvenus enfin à la troisième période, celle où la S.D.N. pregnant la Codification sous son égide, va lui ouvrir des voies nouvelles et lui imprimer son veritable caractère." J Gustave Guerrero, $L a$ Codification du Droit International (A. Pedone 1930) 15.

38 Baker, $\mathrm{n} 12,61$.

39 Preamble of the First Resolution. Permanent Court of International Justice, Advisory Committee of Jurists, Procès-Verbaux of the Proceedings of the Committee, June $16^{\text {th }}$ - July $24^{\text {th }} 1920$, with Annexes (1920) 747 .

40 Ibid.

41 The objectives were, among others, "[r]e-establishing the existing rules of the Law of Nations, ..." and "[f]ormulating and approving the modifications and additions rendered necessary or advisable by the War, and by the changes in the conditions of international life following upon this great struggle". Ibid. Ibid 748 . 
It was four years after the adoption of this resolution that the League of Nations took up the issue by appointing the Committee of Experts for the Progressive Codification of International Law. ${ }^{43}$ When the League of Nations Conference for the Codification of International Law was finally convened at The Hague in March 1930, the fluidity and indeterminacy of the concept of codification and the concomitant question, that is, the diplomatic and political character involved in the process, proved to be points of substantial controversy. The Preparatory Committee composed of five experts (formed in 1927 and chaired by Basdevant from France) prepared, in addition to the "Bases of Discussion", the Draft Rules for the Conference. Article 25 of the Draft Rules provided that "Declarations by which the signatory Governments will recognise certain principles as being sanctioned by existing international law may also be signed as acts of the Conference ..." ${ }^{44}$ This provision, which reflected the conception of codification held by the Preparatory Committee, was agreed to be deleted at the fifth plenary meeting. ${ }^{45}$ As a result, only conventions were supposed to be produced at the Conference. ${ }^{46}$ This episode illustrates the persistence of the controversy around the meaning of codification.

It is also to be noted that a heated debate ensued over the question of whether the conventions adopted according to article 20 of the Rules of Procedure would, as "codified law", be "binding on all States, even on those which do not accede to [them]". ${ }^{77}$ This question was put to rest by the powerful intervention of Rolin (Belgium) who, after pointing out the difficulty of maintaining the distinction "between pure codification and the adoption of new rules", affirmed that "in so far as any such instrument would go beyond existing international

43 League of Nations, 'Resolution adopted by the League of Nations Assembly on 22 September 1924' (1924) League of Nations Official Journal Spec Supp 21, 10.

44 League of Nations, Acts of the Conference for the Codification of International Law: Vol. I, Plenary Meetings (1930) 65 (emphasis added).

45 Ibid 29. A historical survey prepared by the United Nations Division of Development and Codification of International Law called the debate on whether to retain article 25 of the draft rules "the first and perhaps the most important question" among the questions of procedure. United Nations, 'Historical Survey of Development of International Law and its Codification by International Conferences' (1947) 41(4) AJIL (Supp: Official Documents) 81 .

46 According to the memorandum prepared by the United Nations Secretariat entitled "Progressive Development of International Law and Codification" (A/122, 17 October 1947) 5 , "sentiment at the Conference rapidly developed against making any such distinction [between 'conventions' and 'declarations'], and even the idea of having any declarations at all was opposed." The deletion of article 25 of the draft rules of procedure reflected such a sentiment.

Guerrero (Salvador) answered in the positive to this question. League of Nations (n 44) 33 . 
law, it would ... only bind the States acceding to it."48 Nevertheless, a high degree of uncertainty persisted about the meaning and normative impact of codification at this Codification Conference. ${ }^{49}$

In the light of such divergence of opinions on some of the basic questions of the Conference, it is not surprising that the 1930 Codification Conference produced a disappointing result, ${ }^{50}$ even though some commentators tried to put it in a positive light. ${ }^{51}$ In a 1946 speech before the Grotius Society, a well-known authority suggested that the "mixing-up" of codification as "ascertaining and declaring the existing rules of international law" and codification as "amending law as well as defining it, so that the provisions in the code shall state the rules of international law as they ought to be" was the main cause of failure of the 1930 Conference..$^{52} \mathrm{He}$ went on to argue that the job of clarifying and defining the broad principles of international law could not be undertaken by governments. ${ }^{53}$ For the tackling of these persistent questions, international society had to wait for another fifteen years.

This historical overview on the evolution of the codification of international law since the late 18th century until the end of the Second World War highlights some of the core questions surrounding the idea of codification in international relations, in particular the distinction between "consolidating codification" and codification of a legislative character. It also shows that the identity and capacity of codifiers remained an important question throughout the evolution of the idea of codification of international law. In

48 Ibid 33-34.

49 A historical survey prepared by the United Nations points out some difficulty the Conference encountered "in drawing a distinction between codifying existing and drawing up new rules of international law”. United Nations (n 45) 85 .

50 Judge Ago observed that "la Conférence de La Haye de 1930 dut enregistrer un échec presque complet." Roberto Ago, 'La Codification du Droit International et les Problèmes de sa Réalisation' in Recueil d'Études en Droit International en Hommage à Paul Guggenheim (La Tribune de Genève, 1968) 101. The 1947 historical survey discusses "Reasons for Failure of the [Hauge] Conference". United Nations (n 45) 84-86.

$5^{1}$ For instance, Manley O Hudson, "The First Conference for the Codification of International Law" (1930) 24 AJIL 447, 465-466; Green H Hackworth, 'Responsibility for States for Damages caused in their Territory to the Person or Property of Foreigners: The Hague Conference for the Codification of International Law' (1930) 24 AJIL 500, 515.

52 Cecil Hurst, 'A Plea for the Codification of International Law along New Lines' (1946) 32 Transactions of the Grotius Society 135, 146.

53 Ibid., p. 148. For a view critical of Hurst's position, see Hersch Lauterpacht, 'Codification and Development of International Law' (1955) 49 AJIL 16, 34 ("so-called private codification must assume its proper place as a desirable aid and stimulus to official activity in this field"). 
the following, I will look into how these questions played out in the United Nations era when the codification of international law was provided with a "statutory basis".

\section{Diverging Conceptions of Codification within the Inaugural International Law Commission}

The codification of international law in the post-1945 period was founded on Article 13(1)(a) of the Charter of the United Nations. In stark contrast to the Covenant of the League of Nations, the Dumbarton Oaks proposals of 1944, which constituted the basis for the Charter, were characterized by the absence of recognition of the role of law in the international community. ${ }^{54}$ At the San Francisco Conference, some governments tried to fill this gap, if insufficiently, by adopting Article 13(1)(a) of the Charter which reads: "The General Assembly shall initiate studies and make recommendations for the purpose of: (a) ... encouraging the progressive development of international law and its codification." 55

The implementation of Article 13(1)(a) was undertaken in the second part of the first session, leading to the appointment of the Committee for the Progressive Development of International Law and its Codification (also known as the "Committee of Seventeen") on 11 December $1946 .{ }^{56}$ The Committee held its

54 At the San Francisco Conference, this deficiency of the Dumbarton Oaks proposals was pointed out by several governments, in particular, by the Egyptian Government which stated that "the draft Agreement does not mention the principles of International Law as being the basis of the new Organization." It also suggested that "the new Organization should ndeavor to further and develop International Law either by the channel of some special agency depending on the General Assembly, or through the existing Economic and Social Council." (emphasis added) Documents of the United Nations Conference on International Organization, San Francisco 1945, vol III 447, 448; Herbert W Briggs, The International Law Commission (Cornell University Press 1965) 3.

55 For a detailed discussion of the "legislative history" of this provision, see Yuen-Li Liang, "The General Assembly and the Progressive Development and Codification of International Law' (1948) 42 AJIL 66, 66-68. See also Rosenne (n 25) 109-122; Briggs (n 54) pt 1. According to Rosenne, the very idea of providing for the progressive development and codification of international law in the constituent instrument of the United Nations Charter was "revolutionary". Rosenne (n 25) 111. Jennings saw "nothing novel" in Article (13)(a) of the UN Charter. According to him, this provision stands in "a continuous history extending over rather more than a century". RY Jennings, "The Progressive Development of International Law and its Codification' (1947) 24 BYIL 3 o1. UNGA Res 94(I) (11 December 1946). 
first meeting on 12 May 1947, adopting the report of the Rapporteur (J.L. Brierly of the United Kingdom) on 13 June 1947. ${ }^{57}$

In the course of the Committee's discussions, the distinction between progressive development and codification of international law appeared as one of the core problems. Brierly and Jessup (United States of America) supported the distinction between the two. According to Brierly, codification was a scientific task to be carried out by "a small committee of personal experts", 58 while the adoption of conventions necessarily brought in political factors. ${ }^{59} \mathrm{In}$ contrast, Koretsky (Soviet Union) supported "only one of the methods, namely, that of international conventions [the other being the method of scientific restatements']." ${ }^{\prime 0}$ In the end, the Committee adopted the final report in which a distinction between progressive development and codification of international law was drawn merely "for convenience". 61

In the report, the Committee recommended the General Assembly to establish the International Law Commission for the purpose of carrying out the progressive development of international law and its eventual codification. After presentation of the Committee's report to the General Assembly, the Second Sub-Committee of the Sixth Committee was tasked with the drafting of the statute of the International Law Commission. The General Assembly adopted the statute on 21 November 1947, although it decided to postpone the election of the inaugural Commission until $1948 .{ }^{62}$

In discussing various conceptions of codification of international law, it is worthwhile to revisit the discussions which took place at the inaugural session of the International Law Commission (1949). At the first meeting of the first session, Mr. Kerno, Assistant Secretary-General made opening remarks. Even though the dark clouds of what would be subsequently known as the "Cold War" loomed menacingly large, it is not surprising, given the nature of

57 Liang ( $\mathrm{n}_{55}$ ) 69-7o. During the period between the constitution of the Committee and the first meeting, the Division of Development and Codification of International Law of the Secretariat carried out preliminary studies, producing a series of documents, including a historical survey of the development of international law and its codification by international conferences ( $\mathrm{n} 45)$.

$5^{8} \quad$ UN Doc A/AC.10/SR.2 (13 May 1947) 5 .

$59 \quad$ Liang (n 55) 74.

6o UN Doc A/AC.10/SR.9 (24 May 1947) 13; Liang (n 55) 75; Rosenne (n 25) 116.

61 United Nations, 'Report of the Committee of the Progressive Development of International Law and its Codification on the Methods for Encouraging the Progressive Development of International Law and its Eventual Codification' UN Doc A/AC.10/51 (17 June 1947) 41(3) AJIL (Supplement: Official Documents) 20. UNGA Res 174(II) (21 November 1947) and 175(II) (21 November 1947). 
the occasion, to see him utter optimistic remarks on the role of international law. He likened international law to "a great and ancient edifice the doors of which were being opened so that it could be put in order, as it had to serve as a shelter to mankind." 63 With regard to codification as provided for in Article 13 of the Charter of the United Nations, he opined that "codification should be looked upon as forming part of a comprehensive, long-range plan for the eventual codification of international law as a whole." ${ }^{4}$

Mr. Kerno's high hopes pinned on the newly established International Law Commission appear to be reflective of similar sentiments expressed in the memorandum submitted by the Secretary-General titled "Survey of International Law in Relation to the Work of Codification of the International Law Commission". ${ }^{65}$ In the memorandum, the ultimate object of the Commission was presented as "the eventual codification of the entirety of international law." 6 One is struck by the fact that the author of the memorandum believed that the object of the Commission could be achieved in a relatively short period of time ("in two decades or so" 67 or "over a period which may cover a generation"). ${ }^{68}$ Through its work of codification, the Commission would, among others, enhance the authority of international law through "the introduction of certainty, precision and uniformity in matters of detail." ${ }^{\prime 9}$ The Commission was afforded "the opportunity, long awaited, of removing a grave defect in international law and of enhancing its usefulness and authority as a true system of law".70

While acutely aware of the differences between the mandate of the League of Nations' Committee of Experts and the International Law Commission, ${ }^{71}$ the Secretary-General's memorandum proceeded from the premise of strong continuity between the two. We have already seen that the roots of the Commission's mandate of progressive development and codification of international law can be traced down to the 19th century, when scholarly efforts at

\footnotetext{
63 [1949] ILC Ybk 9 at para 2 (emphasis added).

64 Ibid 9 at para 4 (emphasis added).

65 ILC, 'Survey of International Law in Relation to the Work of Codification of the International Law Commission: Preparatory work within the purview of article 18, paragraph 1, of the of the International Law Commission - Memorandum submitted by the Secretary-General' (1o February 1949) UN Doc A/CN.4/1/Rev.1.

66 Ibid 14 at para 19 (emphasis added).

67 Ibid 17 at para 22.

68 Ibid 62 at para 103.

69 Ibid 8 at para 12.

$70 \quad$ Ibid 70 para 119.

71 Ibid 6o para 101.
} 
codification of international law were undertaken in a systematic way. To draw up a new "Benthamite code" of international law was often put forth as the right course to get rid of war. ${ }^{72}$ This idea was firmly anchored in the desirability and practicability of articulating a uniform and universal code of international law.

At the inaugural session of the International Law Commission, one can easily find some members of the Commission adhering to this traditional idea of codification of international law. Mr. Spiropoulos observed that the Commission could make a strong impression on the General Assembly by announcing that the Commission's ultimate aim was "to give to the world a complete code of international law." ${ }^{33}$ His position was echoed by some Commission members from Latin America, who had substantial experience in the codification of international law, as exemplified by the activities of the "International Commission of American Jurists for the Codification of International Law, Public and Private", which was held in Rio de Janeiro, 19 April - 20 May 1927. For instance, Mr. Alfaro (Panama) pointed out that the International Law Commission's task was "to draft a work that might be entitled: "The Law of Nations Codified." 74 It is evident that such positions and observations aligned with the traditional movement for the codification of international law.

Other members of the Commission voiced opinions which were sceptical or critical of the traditional conception of codification of international law. First, questions were raised concerning the practicality of preparing "a general code of rules of international law."75 Mr. François (Netherlands), who was deeply involved in the codification efforts within the framework of the League of Nations, warned against the overly ambitious approach supported by some members of the Commission. According to him, it was "better to obtain positive results on one or two less important questions than to draw up a general systematic plan which would subsequently prove impracticable." ${ }^{76}$ He went so far as to recommend the method used at the Conference on International

72 Norman Bierman, 'Codification of International Law - A Basis of World Government' (1930) 15 Washington University Law Review 151, 155 .

73 [1949] ILC Ybk 54-55 at para 8o (emphasis added).

74 Ibid 11 at para 25 .

75 Ibid 34 at para 3o. Concerning the approach to be taken by the Commission in its future work, Mr. Spiropoulos observed as follows: "the Commission should decide whether it proposed simply to codify certain subjects of international law, or whether it intended drafting a code of international law." His answer to the question was that the Commission's task would seem rather to be "the preparation of a general code of rules of international law." Ibid.

Ibid 17 at para 20. 
Private Law at The Hague as a model for the International Law Commission. ${ }^{77}$ The fact that Mr. François' suggestion is premised on the heterogeneity and diversity of international society (as is implied by the Anglo-American term "conflict of laws" denoting the subject of private international law) reflected his belief in the absence of "unity of spirit" in the area of public international law. ${ }^{78} \mathrm{Mr}$. Scelle, despite being an ardent proponent of the idea of solidarity in international society and jurisdictional activism of the International Law Commission in its relations with the General Assembly, ${ }^{79}$ went along with Mr. François. Affirming the impossibility of drawing up a general plan of codification, he opined that "the only possible solution was to choose a limited number of topics." 80

Mr. Koretsky (Soviet Union) was highly critical of the traditional idea of codification of international law. According to him, a radical transformation took place in international relations since the first efforts of the League of Nations to codify international law. This profound change in international relations impelled many topics for codification that seemed essential at that time (such as the control of territorial waters and that of nationality) to

give place to other questions which had become of primary importance from the point of view of the maintenance of peace in an international community based on the equality of all States, absolute respect for their sovereignty and the exclusion of any intervention in affairs which fell within their domestic jurisdiction. ${ }^{81}$

He went to observe that " $[\mathrm{t}]$ he question of codification must therefore be completely reconsidered, for it could be solved only by the peaceful co-operation of all forms of civilization, without distinction as to colour, and of all political systems of whatever shade of opinion." 82

Under such understanding, codification of international law should be geared toward articulation of "progressive" principles of international law that would contribute to the peaceful co-existence of nations (or blocs) with widely differing political systems and ideologies. This understanding diverges

$77 \quad$ Ibid 17 at para 22.

78 Ibid 17 at para 20.

79 According to Scelle, in the selection of suitable topics for codification, the Commission was "a body with complete freedom, the equal of the International Court of Justice." Ibid 19 at para 45 .

8 o Ibid 34 at para 36 .

81 Ibid 29 at para 5 o.

82 Ibid 29 at para 51 (emphasis added). 
radically from the traditional idea of codification of international law premised on the homogeneity of international society.

This short analysis of the first meetings of the Commission shows that the members of the inaugural Commission harboured widely diverging views of the term "codification." The traditional idea of codification of international law was founded on the basic homogeneity of international society. This led some members of the Commission to propose a wholesale codification of international law ("Law of Nations Codified"). Other members, while not discarding the thesis of homogeneity of international society, proposed a more practical approach of selecting a limited number of international law topics for codification. In contrast, Mr. Koretsky, keenly aware of the profound transformation which took place in international relations since the 1920s, put forth a radically different concept of codification (and a very different list of topics to be "codified"). Shabtai Rosenne has argued that the success of the International Law Commission in the first 25 years of its codification efforts was paradoxically attributable to the international tension brought on by the Cold War. According to him, the instruments adopted by the Commission during that period supplied "a basic agreed code for their mutual contacts in periods of high tension and suspicion." 83 This is assessed as "legal diplomacy at its best." 84

Now one needs to investigate how the divergence on the conception of codification of international law as demonstrated by the discussions at the inaugural session of the International Law Commission was subsequently addressed by the Commission.

\section{The Evolution of the Concept of Codification within the United Nations and a Taxonomy of Codification Carried out by the International Law Commission}

In the post-1949 period, the question of distinguishing between progressive development and codification of international law and the tension between the academic and diplomatic character of the Commission's work appear to have all but lost their poignancy. The rather abstract mandate for the General Assembly as stipulated in Article 13, paragraph 1 (a) of the Charter of the United Nations has been concretized and clarified by the subsequent practice relating to the provision.

83 Shabtai Rosenne, 'Codification Revisited After 5o Years' (1998) 2 MaxPlanckYrbkUNL 1, 11.

84 Ibid 13 . 
The substantive and procedural elaboration of the provision by the Committee for the Progressive Development of International Law and its Codification was discussed above. The distinction between progressive development and codification of international law, as provided for in the statute of the International Law Commission "for convenience", was acutely taken cognizance of by the Commission in its early years. For instance, the first report submitted by the inaugural Special Rapporteur on the law of treaties, J.L. Brierly, started with the question of "whether to confine his attention strictly to the law as it may be generally acknowledged to be, or to suggest what are in his view improvements in the existing law." ${ }^{85}$ In handling one of the first tasks entrusted by the General Assembly, the draft declaration on rights and duties of States, ${ }^{86}$ the Commission asked under which of its two principal duties, i.e. progressive development or codification of international law, the assigned task fell. The Commission concluded that it fell under neither of them, but constituted a special assignment from the Assembly. ${ }^{87}$

In the final report presenting the draft articles on the law of the sea, ${ }^{88}$ the Commission admitted as follows:

In preparing its rules on the law of the sea, the Commission has become convinced that, in this domain at any rate, the distinction established in the statute between [progressive development and codification of international law] can hardly be maintained. ... Although it tried at first to specify which articles fell into one and which into the other category, the Commission has had to abandon the attempt, as several do not wholly belong to either. ${ }^{89}$

85 [1950] II ILC Ybk 224 at para 2. He also enumerated the principal existing drafts on the law of treaties. Ibid 225-226 at paras 11-12.

86 [1949] ILC Ybk 287.

87 Ibid 290 at para 53 .

88 [1956] II ILC Ybk 256.

89 Ibid $255^{-256}$ at para 26 . Although the Commission initially worked on the regime of the high seas and that of territorial waters separately, in 1956 it produced a single set of draft articles dealing with the "problems relating to the high seas, territorial waters, contiguous zones, the continental shelf and the superjacent waters" that "were closely linked together juridically as well as physically". UNGA Res 899(IX) (14 December 1954). At the first United Nations Conference on the Law of the Sea, it was decided to divide the Commission's draft into four conventions. Among the conventions, the Convention on the High Seas (adopted 29 April 1958, entered into force 30 September 1962, 40 UNTS 11) affirms in its preamble that "[the Conference] adopted the following provisions as generally declaratory of established principles of international law." It also stated that the States Parties to the Convention desired to "codify the rules of international law relating to the high seas" 
Concerning the subject of "diplomatic intercourse and immunities" where "la plupart des règles qui existent ont été formé par la coutume et la tradition", ${ }^{90}$ it was no wonder that some Commission members regarded their task as ascertaining existing principles and rules, ${ }^{91}$ this field of law being "one of the subjects least open to innovation". ${ }^{92}$

If one fast-forwards to the recent work of the International Law Commission, one hardly comes across the distinction between the two categories of activities. Despite all the efforts made for the distinction between the two, in particular, the different working methods elaborately stipulated in articles 16 to 24 of the Commission's statute, ${ }^{93}$ the practice of the Commission evolved towards a merger of the two distinct procedures into one consolidated and practical method. ${ }^{94}$ According to Judge Sette-Camara, this development represents "the Commission's wisdom in departing from the original perception of its mandate as comprising two watertight compartments and, without the need for any amendment of its statute, evolving towards a consolidated method of work which proved to be fruitful and effective". ${ }^{5}$

That the International Law Commission by now operates without being burdened by the distinction between the two types of function is well illustrated by the Commission's work on "Fragmentation of international law: difficulties arising from the diversification and expansion of international law". First of all, questions were raised at the initial stage of the work whether the topic was

(emphasis added). As far as the law of the high seas is concerned, the "confession" of the "codifiers" to the impossibility of the distinction between progressive development and codification of international law was overridden by the 1958 Conference.

$90 \quad$ A.E.F. Sandström, 'Diplomatic intercourse and immunities. Rapport presente par M. A. E. F. Sandström, rapporteur special' [1955] II ILC Ybk 9, 14 at para 14.

91 This was the view of Yokota; [1957] I ILC Ybk 3 at para 12.

92 Garcia Amador; ibid 3 at para 21.

93 Chapter 2 of the statute ("Functions of the International Law Commission") is composed of Section A, providing for the procedures to be followed in progressive development of international law, and Section B, providing for the procedures for codification of international law. The two procedures are very different from each other. For instance, Section B does not mention the appointment of a Special Rapporteur.

94 Sette-Camara (n 2) 483. Lauterpacht welcomed the merger of the two methods through the practice of the Commission. Lauterpacht (n 53) 30. A former member of the Commission goes so far as to state that "a transition from codification stricto sensu to progressive development of international law currently takes place." Gerhard Hafner, 'Codification and Progressive Development of International Law' in Franz Cede and Lilly Sucharipa-Behrmann (eds), The United Nations: Law and Practice (Martinus Nijhoff 2001) 152.

Sette-Camara (n 2) 487 . 
suitable for study by the International Law Commission. The Commission itself recognized "the unique nature of the topic". ${ }^{96}$ The substantive uniqueness of the subject was later "tamed" by the decision "to set aside the institutional implications of fragmentation" and to "focus work on the Vienna Convention [on the Law of Treaties]". ${ }^{97}$

Procedurally, the Commission took a highly innovative approach. For the first time in its history, the Commission formed a "Study Group" to carry out the work, which fell under neither progressive development nor codification. In a significant departure from the well-established practice of the Commission, no Special Rapporteur was appointed. ${ }^{98}$ The outlines and studies produced in the process leading to the finalization of the work (the final product was composed of (i) a relatively large analytical study on the question of fragmentation and (ii) a single collective document containing a set of conclusions) ${ }^{99}$ have not been published officially. ${ }^{100}$ The Commission, rather than adopting, took note of the forty-two conclusions and commended them to the attention of the General Assembly. ${ }^{101}$

It is evident from this example that the International Law Commission now enjoys a substantial degree of discretion in choosing its subjects, methods of work and the forms of the final outcome (admittedly, subject to interaction and cooperation with the General Assembly). As far as the Commission is concerned, the centuries-old debate over various meanings of codification, in particular the distinction between progressive development and codification of international law, has been all but resolved, without the official amendment of the statute of the International Law Commission, through the subsequent

$96 \quad$ ILC, 'Report of the International Law Commission on the work of its fifty-fourth session' [2002] II (2) ILC Ybk 1, 97 at para 496.

97 ILC, 'Report of the International Law Commission on the work of its fifty-sixth session' [2004] II(2) ILC Ybk 1, 111 at para 302. As a result, the Commission's work on fragmentation of international law can be regarded as falling largely under the category of "annotative codification", a concept which will be elaborated later.

98 Arnold Pronto and Michael Wood, The International Law Commission 1999-20og, Volume IV: Treaties, Final Draft Articles, and Other Materials (oup 2010) 6og.

99 ILC, 'Report of the International Law Commission on the work of its fifty-eighth session' [2006] II(2) ILC Ybk 175 at para 235. This unique composition of the final outcome of the Study Group's work gave rise to a discussion as to what measures should be taken on the two components of the report. See [2006] I ILC Ybk 240 at para 6.

100 Pronto and Wood (n 98) 611.

101 ILC report 2006 (n 99) para 239; Pronto and Wood (n 98) 611. On December 20o6, the General Assembly took note both of the 42 conclusions and the "analytical study on which they were based". UNGA Res 61/34 (4 December 2006). 
practice relating to the work of the Commission. ${ }^{102}$ Reflecting such an evolution within the International Law Commission, I will subsume both activities of the Commission as stipulated in its statute under the nomenclature of codification in the following discussion.

Given the large number of topics the Commission has dealt with and the enormous amount of materials it has produced, it is beyond my ability to offer an assessment of the Commission's work over the past seven decades. A large number of proposals for the improvement of the Commission's work, in particular, the proper role of the Commission (such as "the role of an International Law Research Center"103 or "the role of an advisory body along the lines of the Commission of Jurists of the League of Nations"), ${ }^{104}$ its working methods, ${ }^{105}$ the selection of topics, ${ }^{106}$ the Commission's relationship with other relevant bodies, ${ }^{107}$ have been made. In this paper, I will not walk again this well-trodden path. Instead, I will venture a taxonomy of various conceptions of codification discussed and conducted within the Commission. As will be made clear soon,

102 The distinction between progressive development and codification of international law is still relied on by States within the Sixth Committee, in particular when they find the Commission's proposal or work to be de lege ferenda. For instance, the United Kingdom delegation observed concerning the topic of responsibility of international organizations that "limited availability of pertinent practice moved several of the draft articles in the direction of progressive development, rather than codification." UN Doc A/C.6/66/ SR.19, 3 at para 9. For a suggestion that the distinction be maintained within the ILC, see Franklin Berman, 'The ILC within the UN's Legal Framework: Its Relationship with the Sixth Committee' (2006) 49 GYIL 107, 127.

103 Julius Stone, 'The Vocation of the International Law Commission' (1957) 57 ColumLRev $16,49-51$.

104 Hisashi Owada, 'The International Law Commission and the Process of Law-Formation' in Making Better International Law: The International Law Commission at 5o, Proceedings of the United Nations Colloquium on Progressive Development and Codification of International Law (United Nations 1998) 180. For a critical view on this suggestion, Christian Tomuschat, 'L'Exemple de la Commission du Droit International' in Société Française pour le Droit International (ed), Colloque d'Aix-en-Provence : La Codification du Droit International (Pedone 1999) 190.

105 Christopher Pinto, 'The International Law Commission: Methods of Work and Selection of Topics' in Making Better International Law: The International Law Commission at 5o, Proceedings of the United Nations Colloquium on Progressive Development and Codification of International Law (United Nations 1998) 233-255.

106 For instance, Franz Cede, 'Das künftige Arbeitsprogramm der ILC' in Völkerrecht zwischen normativem Anspruch und politischer Realität: Festschrift für Karl Zemanek zum 65. Geburtstag (Duncker \& Humblot 1994) 25-43; Tomuschat (n 105) 179-182; Karl Zemanek, 'Codification of International Law: Salvation or Dead End?' in International Law at the Time of its Codification: Essays in Honour of Roberto Ago, vol 1 (Giuffrè 1987) 59o-596.

107 For instance, Berman (n 102). 
this taxonomy is not offered only for descriptive purposes; it will serve some prescriptive purposes as well.

First, we have seen above that in the 19th century, the term codification was largely understood as articulation of a complete code of international law or production of a single-volume code of the entire law of nations. This conception of codification was, among others, influenced by what a leading Japanese commentator perceptively termed "domestic model centrism" in international law. Domestic model centrism means our habit of conceptualizing and evaluating international law based on the (idealized) model of domestic law. When engaging in international law discourse, people "- mostly unconsciously - tend to assume the domestic law of the (modern) state as a frame of reference." 108 Codification in this vein can be called "total codification" or "mega-codification" which, despite the strong support expressed by Spiropoulos and Alfaro at the inaugural session of the Commission, appears not so "realizable" (to use the term employed by the League of Nations). Due to its impracticality, the Commission did not pursue this conception of codification.

Second, now left with the only option of choosing a limited number of topics for codification, the Commission sometimes took up subjects that constitute the very foundation or architecture of international law as a system of law. The Commission's work on the law of treaties, diplomatic relations, State responsibility, and the law of the sea could be adduced as appropriate examples. It would be fair to say that the impact and contribution of the International Law Commission is most strongly felt through its codification efforts in these areas of international law. The 1969 Vienna Convention on the Law of Treaties ${ }^{109}$ is accepted by almost all States as "a working statement of the applicable rules by which they can in practice be guided in their international dealings".110 The International Court of Justice in many contexts treated the provisions of the Vienna Convention as representing a codification of customary international law. ${ }^{111}$ The 2001 articles on responsibility of States for internationally wrongful acts, ${ }^{112}$ although not adopted as a convention, made a substantial contribution

\footnotetext{
108 Onuma Yasuaki, International Law in a Transcivilizational World (oup 2017) 2.

109 Adopted 23 May 1969, entered into force 27 January 1980, 1155 UNTS 331.

110 Arthur Watts, The International Law Commission 1949-1998, vol 2 (ou P 1999) 613.

111 Ibid. For a list of recent cases of the International Court of Justice where the Court declared certain provisions of the Vienna Convention on the Law of Treaties reflective of customary international law, see Stefan Talmon, 'Determining Customary International Law: The ICJ's Methodology between Induction, Deduction and Assertion' (2015) 26(2) EJIL 417,437 at footnote 145 .

112 UNGA Res 56/83 (12 December 2001), annex.
} 
to the exposition not only of the law of State responsibility itself, but also of fundamental questions relating to the normative structure of international society through their tackling of, among others, serious breaches of obligations arising under peremptory norms of general international law and obligations erga omnes. These articles are frequently utilized and invoked by States and other actors of international law. For instance, the International Court of Justice found the provisions of the articles as reflecting customary international law. ${ }^{113}$ The 1961 Vienna Convention on Diplomatic Relations ${ }^{114}$ is regarded as "a cornerstone of the modern international legal order" by the author of a leading textbook on the subject. ${ }^{115}$ In these examples, the Commission can be said to have engaged in "foundational or architectural codification".116

Third, the Commission also chose topics that fall under the "special part" of international law. Various topics relating to State succession, jurisdictional immunities of States and their property, nationality including statelessness, protection of persons in the event of disasters, various topics relating to international criminal law, protection of the atmosphere, internationally protected persons and most favoured nation clauses can be adduced as examples. These exercises could be called "thematic codification".

The Commission made a great contribution to the clarification and systematization of international law in these diverse fields, although it has to be admitted that the Commission's work on some topics, for instance, arbitral procedure and most-favoured nations clause, could not be judged to be successful. Some of these topics were selected based on the discussion of the 1949 survey of international law by the Secretary-General, ${ }^{117}$ thus constituting rather traditional subjects of international law. Others were selected based on the needs felt by the international community. The Commission's work leading to the adoption of the Convention on the Prevention and Punishment of Crimes

113 For instance, in Gabčikovo-Nagymaros Project (Hungary/Slovakia) [1997] ICJ Rep 7, the International Court of Justice placed reliance on article 33 of the draft articles on the responsibility of States which the Commission adopted on first reading. An extensive overview of recent references by international courts and tribunals to the articles on State responsibility can be found in United Nations, Materials on the Responsibility of States for Internationally Wrongful Acts (United Nations Legislative Series 2012); and United Nations, 'Responsibility of States for internationally wrongful acts. Compilation of decisions of international courts, tribunals and other bodies' (2016) UN Doc A/71/8o.

114 Adopted 18 April 1961, entered into force 24 April 1964, 500 UNTS 95.

115 Eileen Denza, Diplomatic Law: Commentary on the Vienna Convention on Diplomatic Relations ( $4^{\text {th }}$ edn, OUP 2016) 1.

116 I acquired the hint for the expression "architectural codification" from the book of Professor Watts. Watts (n 1$) 6$.

117 ILC (n 65). 
against Internationally Protected Persons including Diplomatic Agents ${ }^{118}$ is an apt example of the latter type. On the request made by the General Assembly in December 1971, the Commission submitted its draft articles in July 1972. ${ }^{119}$ The General Assembly adopted the Convention in December 1973. This showed that the Commission could deal rapidly and successfully with "matters to which the General Assembly ... attached real political urgency". ${ }^{20}$

Fourth, not a small amount of the Commission's work has been devoted to what one could call "complementary or annotative codification". The Commission expanded the scope of application of the 1969 Vienna Convention on the Law of Treaties by producing the draft articles that led to the adoption of the 1986 Vienna Convention on the Law of Treaties between States and International Organizations or between International Organizations, ${ }^{121}$ although it is true that the latter Convention contained a number of provisions that reflected the peculiarities of international organizations. ${ }^{122}$ The same could be said concerning the 2001 articles on responsibility of States for internationally wrongful acts and the 2011 articles on the responsibility of international organizations, although the latter contain provisions dealing with matters specific to international organizations (for example, articles 61 and 62 ). ${ }^{123}$ The articles on State responsibility, on the one hand, and the two international liability projects ("Prevention of transboundary damage from hazardous activities"124 and "International liability in case of loss from transboundary harm arising out of hazardous activities"), ${ }^{125}$ on the other, can be characterized in a similar way.

118 Adopted 14 December 1973, entered into force 20 February 1977, 1035 UNTS 167.

119 ILC, 'Draft articles on the prevention and punishment of crimes against diplomatic agents and other internationally protected persons' [1972] II ILC Ybk 312.

120 Watts (n 1) 11, 415-417.

121 Adopted 21 March 1986, not yet in force, A/CONF.129/15. See Watts (n 1) 614 ("No work on the law of treaties could be regarded as complete if it did not also deal with treaties to which international organizations were parties.")

122 Professor Rosenne made a rather harsh assessment of this Convention. Rosenne (n 83) 15 ("Much of this is unchanged repetition of provisions already included in the major Vienna Convention on the Law of Treaties of 1969").

123 The complementary character of part five of the 2011 articles on the responsibility of international organizations is indicated in the Commission's commentary. ILC, 'Draft articles on the responsibility of international organizations' [2011] II(2) ILC Ybk 40, 96 (general commentary to part five, para 1: "In accordance with article 1, paragraph 2, the present draft articles are intended to fill a gap that was deliberately left in the articles on responsibility of States for internationally wrongful acts.") (emphasis added).

124 ILC, 'Draft articles on prevention of transboundary harm from hazardous activities' [2001] II(2) ILC Ybk 146.

125 ILC, 'Draft principles on the allocation of loss in the case of transboundary harm arising out of hazardous activities' [2006] II(2) ILC Ybk 58. 
The Commission engages in what one could term "annotative codification" when it expands on, or further clarifies, some of the provisions or issues that are already regulated by foundational or thematic codifications. When one looks at the analytical guide to the work of the International Law Commission, ${ }^{126}$ one is struck by the preponderance of the Commission's work falling under this category. In particular, the "annotative codification" in the law of treaties has been and is quite conspicuous. Reservations to treaties (in addition to the work of the Commission on "reservations to multilateral conventions" which was in the nature of "special assignment" by the General Assembly), subsequent agreements and subsequent practice in relation to interpretation of treaties, provisional application of treaties and peremptory norms of general international law (jus cogens) can be adduced. As was pointed out above, "fragmentation of international law: difficulties arising from the diversification and expansion of international law", despite its unique character and format, can be regarded as falling under this category.

Outside the law of treaties, the diplomatic courier and the diplomatic bag not accompanied by diplomatic courier falls within this category. This topic expands on the relevant provisions of the 1961 Vienna Convention on Diplomatic Relations and the 1963 Vienna Convention on Consular Relations. ${ }^{127}$ The necessity of the Commission's work on this topic was justified based on the increasing number of violations of the relevant part of the diplomatic and consular law. ${ }^{128}$ The Commission's work, based on the recognition that "the rules on [the status of the diplomatic courier and the diplomatic bag] contained in the four codification conventions needed to be further elaborated"129(thus

126 Available at <http://legal.un.org/ilc/guide/gfra.shtml>.

127 Adopted 24 April 1963, entered into force 19 March 1967, 596 UnTS 261. The primary purpose of the draft articles prepared by the Commission was to "establish a coherent and, in so far as possible, uniform régime governing the status of all kinds of couriers and bags, on the basis of the 1961 Vienna Convention on Diplomatic Relations, the 1963 Vienna Convention on Consular Relations, the 1969 Convention on Special Missions and the 1975 Vienna Convention on the Representation of States in their Relations with International Organizations of a Universal Character". ILC, "Report of the International Law Commission on the work of its forty-first session' [1989] II(2) ILC Ybk 1, 9 at para 31. While the Special Rapporteur had originally proposed a "global concept of 'official courier and official bag'" (ibid 10 at para 37), the Commission decided to "confine the scope of the articles to diplomatic and consular and courier bags as well as couriers and bags of permanent missions and delegations". ILC, 'Draft articles on the status of the diplomatic courier and the diplomatic bag not accompanied by diplomatic courier and draft Optional Protocols thereto' [1989] II (2) ILC Ybk 14 (commentary to article 1, para 3).

128 [1980] II(1) ILC Ybk 245.

129 ILC report 1989 (n 127) 12 at para 58. Rosenne wondered aloud when he said "But did this [the subject of diplomatic courier and the unaccompanied diplomatic bag] require 
confirming the "annotative" nature of the work), was criticized during the debates in the Sixth Committee and in the written observations by some States for the lack of consideration in terms of priority and urgency. ${ }^{130}$

\section{Lessons to Be Drawn From the Taxonomy of Codification}

As mentioned above, the taxonomy of the Commission's codification, which no doubt runs the risk of over-simplification that is compounded by overlap among the different categories, was for "prescriptive" purposes, that is, to help the Commission take stock of its codification efforts extending over 70 years and reaffirm and recalibrate its main function, "the promotion of the progressive development of international law and its codification".

A lesson to be drawn from the taxonomy of the Commission's codification is that it would be desirable to have a proper balance between the different kinds of codification. From the analytical guide to the work of the International Law Commission, one might get the impression that the overall balance is skewed in favour of the annotative codification, in particular, in the law of treaties.

It is often said that the days of codification in the proper (and the grand) sense of the word are over. ${ }^{131}$ According to Professor Watts, "the large architectural subjects having been mostly dealt with, the Commission is now inevitably left with more compact items - none the less important for that, although less eye-catching." ${ }^{132}$ When one turns one's eyes to the field of "thematic codification", the Commission faces various challenges. Some topics have already been handled by other learned bodies, notably, the Institut de Droit international and the International Law Association.

More serious challenges are posed for the Commission in those areas of "thematic codification" where concern is raised over the possible conflict with the ongoing negotiations between States. For instance, when the Commission proposed the topic of protection of the atmosphere, some States (including all

a draft convention running to 32 articles together with two protocols, adopted by the Commission in 1989, only to be buried by the General Assembly [in] 1995?" Rosenne (n 83 ) 16. For a similar critical view of the draft articles, see Denza (n 115) 204-207.

130 ILC report 1989 (n 127) 9-10 at para 33 .

131 McRae (n 3$) 87$.

132 Watts (n 1 ) 6. A keen observer of the Commission and a former insider, Mr. Tomuschat, observed in an even darker tone: "Since the structural needs of codification have been largely satisfied after many decades of intense work, the ILC will probably more often have to face up to actual urgencies as legal counsel of the GA." Tomuschat (n 4) 104-105. 
permanent members of the Security Council) advised the Commission "not to attempt to codify rules in that area at present".133 Such a position seems to be based on the view that it is preferable to entrust newly emerging issues of international law to "policy decision at the political level" rather than to legal regulation. ${ }^{134}$ The Commission upended such reservations, inter alia, by assuring that its work on the topic would not interfere with related political negotiations and that the final outcome of the work on the topic would be a set of draft guidelines. ${ }^{135}$ Concern along similar lines was expressed on the topic of crimes against humanity with particular reference to the regulation of the crime by the Rome Statute. ${ }^{136}$

Under the circumstances, it is not surprising that the Commission's substantial workload has been and is devoted to the complementary or annotative codification expanding on its own former "foundational" or "architectural" codification work. Take, for example, the 1969 Vienna Convention on the Law of Treaties. Considering the obvious utility of the work involved (given the primordial importance of treaties in the construction and management of international relations $)^{137}$ and the concomitant political, or diplomatic, acceptability, coupled with the firmly established authority of the 1969 Convention, the law of treaties can be said to constitute a kind of "comfort zone" (as far as the selection of topics is concerned) for the Commission. ${ }^{138}$

133 Shinya Murase, 'First report on the protection of the atmosphere' (2014) UN Doc A/CN.4/ 667,4 at para 3 .

134 Judge Owada proposed the concept of "international legislation de novo" in addition to codification and progressive development of international law. He is of the opinion that the former is not suitable for consideration by the International Law Commission. Owada (n 104) $174-175$.

135 ILC, 'Report of the International Law Commission on the work of its sixty-eight session' (2016) UN Doc A/68/10, 115 at para 168; Murase (n 133) 4 at para 5.

136 Rome Statute of the International Criminal Court, adopted 17 July 1998, entered into force 1 July 2002, 2187 UNTS 3 .

137 For instance, the discussion on the topic of reservation to treaties within the Sixth Committee in 1997 and 1998 proves this point. Many delegations pointed out that the 1969 Vienna Convention had some "lacunae" or ambiguities as regards reservations. Thailand (UN Doc A/C.6/52/SR.17, para 36), Germany (ibid para 46), Bahrain (ibid para $5^{\circ}$ ), Australia (ibid para $5^{2}$ ), South Africa (ibid para $5^{6}$ ), Korea (UN Doc A/C.6/52/SR.22, para 4), Ghana (ibid para 12), Chile (ibid para 36 ), Russia (ibid para 76 ), Portugal (UN Doc A/C.6/52/SR.24, para 55), Hungary (UN Doc A/C.6/53/SR.19, para 23), Greece (UN Doc A/C.6/53/SR.22, para 44). The practical usefulness of the topic was also stressed. Indonesia (UN Doc A/C.6/52/SR.17, para 44), United Kingdom (UN Doc A/C.6/53/SR.14 para. 15), Sweden (UN Doc A/C.6/53/SR.17, para 4), Portugal (UN Doc A/C.6/53/SR.2o, para 35$)$.

138 Other topics falling within the realm of the law of treaties were approved without much reservation on the part of the General Assembly. Concerning the topic of provisional 
Regarding the selection of the Commission's topics, the current snapshot does not seem to be very encouraging. It is often said that the Commission ran out of topics for foundational, structural or architectural codification. In the field of thematic codification lying beyond the complimentary or annotative codification, the Commission has been (and is) constantly warned not to interfere with or derogate from the pre-existing treaties or agreements or overstep into the "legislative" activities which constitutes a jealously guarded realm for the sovereign States. As a result, in this arena of codification, even after a certain topic has been approved for inclusion into the Commission work programme, the room for manoeuvre for the Commission is substantially circumscribed, particularly, in terms of the form or normative density of its final outcome. It is against such a background that the Commission's work tends to be derivative of its former glories (i.e., the architectural codifications) or runs the risk of handling "actual urgencies as legal counsel of the [General Assembly]".139

One should hasten to add that this sketchy diagnosis does not intend to underestimate in any way the practical importance and utility of the International Law Commission's work and the acute intellectual and diplomatic challenge this work poses for the Commission. This diagnosis was conducted in order to help devise ways for strengthening the raison dêtre of a body charged with the function of no less than "promoting the progressive development of international law and its codification". It is difficult to say that Article 13, paragraph 1 (a) was founded on the very idea of "peace through law", but the provision was

application of treaties, there was some skepticism on the merits of the project. For instance, France (UN Doc A/C.6/SR.20, para 48). However, the topic garnered general support from delegations. Czech Republic (UN Doc A/C.6/SR.18, para 69); Austria (UN Doc A/C.6/SR.19, para 4); United Kingdom (ibid para. 7: the consideration of the topic, while valuable, "should not result in a set of draft articles, but rather in a study of the implementation of article 25" of the 1969 Vienna Convention); USA (ibid para 16); Singapore (UN Doc A/C.6/SR.21, para 80). As regards the topics of subsequent agreements and subsequent practice in relation to the interpretation of treaties, aside from the reservation expressed by the USA (UN Doc A/C.6/62/SR.20, para 24:the United States delegate was "not aware of any pressing real-world issues that necessitated consideration of the topic at the present juncture") and the support from Finland (UN Doc A/C.6/62/SR.18, para 40) and Germany (UN Doc A/C.6/62/SR.19, para 28), the delegations refrained from expressing their opinion on the advisability of adopting the topic. This reticence on the part of the delegations stands in contrast to their approach to the other topics suggested for the Commission's future work, such as expulsion of aliens, most-favoured-nations clause and fair and equitable treatment. This reticence can be interpreted as reflective of the largely uncontroversial and increasingly acceptable character of the topics related to the law of treaties.

Tomuschat (n 4) 104-105. 
adopted in the belief and hope that progressive development and codification of international would contribute to the attainment of the main purpose of the United Nations, i.e. the maintenance of international peace and security.

In connection with (at least, some of) its work, the Commission was keenly aware of the peace-promoting function of international law. For instance, when the Special Rapporteur on State responsibility, Arangio-Ruiz, submitted his seventh report, a member of the Commission thanked him for "his courage in placing the strengthening of the rule of law in international relations before the cold, calculating and selfish realism of the individual interests of States".140 In debates within the Commission about what finally became article 54 of the articles on State responsibility, the view was expressed that the International Law Commission was engaged in "constructing a system of multilateral public order", going beyond its proper function of codifying the law of State responsibility. ${ }^{141}$ I will not conduct a detailed discussion of the thorny question of to what extent (and in what way) the Commission's work is (or should be) geared toward the promotion of peace in international relations. ${ }^{142}$ It is beyond doubt that the Commission's work in the nature of complementary or annotative codification will strengthen the fabric of international law by further clarifying or filling the lacunae of architectural or foundational treaties. It is also true that as a body whose core function is progressive development and codification of international law (an idea with a long pedigree which had the preservation and promotion of international peace as its point of departure), the Commission can be said to carry out its function in a satisfactory manner when it remains active and effective beyond the realm of complementary or annotative codification, in particular, in the field of foundational or architectural codification.

Given the preponderant view that "the field open for new initiatives has considerably shrunk", ${ }^{143}$ how can one come up with ideas for revitalizing the Commission's role in architectural or foundational codification? One way

\footnotetext{
140 [1995] I ILC Ybk 116 at para 47.

141 ILC, 'Report of the International Law Commission on the work of its fifty-second session' [2000] II (2) ILC Ybk 1, 6o at para 365 .

142 For a detailed discussion of the connection between the Commission's work (particularly on State responsibility, the law of treaties and the international law of shared natural resources) and the promotion of peace, see Georg Nolte (ed), Peace through International Law: The Role of the International Law Commission (Springer 20o9). The link between the codification of international law and peace was keenly heeded by an American proponent of the codification of international law. Elihu Root, "The Codification of International Law' (1925) 19 AJIL 675, 681.

143 Tomuschat $(\mathrm{n} 4) 78$.
} 
would be to call into question this preponderant view. Since the establishment of the International Law Commission 70 years ago, the international community has gone through significant transformations. ${ }^{144}$ Even a cursory look at the 1949 survey of international law (and the 1971 survey of international law prepared by the Secretary-General) ${ }^{145}$ reminds one of the structural and substantive changes international law has undergone. As examples, the erosion of ontological centrality (even monopoly) of States within the system, the transfiguration in the discourse of sources of international law (e.g., jus cogens, "soft law"), the (at least, partial) multilateralization of the law of State responsibility (obligations erga omnes as elaborated by article 48 of the 2001 articles on State responsibility) and the emergence of new subject-matters (various environmental questions including global warming, cyber space) can be adduced.

More recent changes that are likely to have an impact on the configuration of international law include, among others, the growing role of non-State actors in the international sphere, the increasing confluence of public and private international law, ${ }^{146}$ and the normative pressure exerted by the "global" on a normative system constructed based on the "inter-State". No less importantly, the challenge posed by the "rise" of new powers could lead to the increasing multiplicity of the international legal order, ${ }^{147}$ as symbolized by the constructively oxymoronic expression "comparative international law". 148 These transformations carry structural or architectural implications that urge responses

144 In the early 1980's, the United Nations Institute for Training and Research submitted a report making proposals for the improvement of the International Law Commission. It started by pointing out "a change in the environment" as represented by the emergence of new States, advances in science and technology, the urgent need for economic and social development, and the demands of the Third World for greater participation in the management of the system. Mohammed El Baradei, Thomas M Franck and Robert Trachtenberg, The International Law Commission: The Need for a New Direction (United Nations Institute for Training and Research 1981) 3-4.

$145[1971]$ II (2) ILC Ybk 1.

146 For a detailed discussion of these questions, see Alex Mills, The Confluence of Public and Private International Law (CUP 2009).

147 Henry Kissinger, On China (Penguin Press 2011); Henry Kissinger, World Order (Penguin Press 2014) 225. ("But [the Chinese] expect - and sooner or later will act on this expectation - the international order to evolve in a way that enables China to become centrally involved in further international rule making, even to the point of revising some of the rules that prevail.")

148 Anthea Roberts, Is International Law International? (OUP 2017); Anthea Roberts, Paul B Stephen, Pierre-Hugues Verdiera and Mila Versteeg (eds), Comparative International Law (OUP 2018). 
from the body tasked with the progressive development and codification of international law.

If, under the circumstances surveyed above, it is difficult for the Commission to undertake another foundational or architectural codification as it did in the 1950's and 196o's, it would be still possible and desirable for the Commission to "turn foundational or architectural" in the field of thematic, complementary and annotative codification. Actually, the Commission has been doing that in respect of certain topics. The conspicuous "architectural gaze" of the Commission on the topic of State responsibility was mentioned above. Another example are the articles on diplomatic protection. ${ }^{149}$ Within the Sixth Committee, many governments heavily criticized the Commission's work on this topic for its tendency to "de-centre" the primordial subject of international law (that is, States). They strongly argued that the conception of the right of diplomatic protection as consecrated by the Mavrommatis Palestine Concessions case should remain intact (despite all the changes in international law that took place over the past century), ${ }^{150}$ attempting to place the topic of diplomatic protection and that of human rights "in clinical isolation" from each other. ${ }^{151}$ The Commission did not blindly incorporate these comments of governments. If it had done so, it would have engaged in a mummification, not codification, of international law. The final outcome of the Commission tries to strike a delicate (even precarious) balance between the traditional, State-centric conception of diplomatic protection and a newly emergent one influenced by the law of human rights. ${ }^{152}$ Similar examples can be provided without much difficulty.

The question can be raised whether the Commission as an institution is equipped to handle such evolution. The statute of the Commission has been said to be characterized by "deliberate elasticity". 153 The Commission's responses to a number of challenges for the past seventy years represent an

149 ILC, 'Draft articles on diplomatic protection' [2006] II(2) ILC Ybk 24.

150 For instance, United Kingdom (UN Doc A/C.6/53/SR.14, para 8); Japan (ibid para 20); France (ibid para 32); China (UN Doc A/C.6/53/SR.15, para 52); Italy (ibid para 73); Mexico (UN Doc A/C.6/53/SR.16, para 17); Uruguay (UN Doc A/C.6/53/SR.16, para 96); Spain (UN Doc A/C.6/53/SR.18, para 45); Cuba (ibid para 52); Slovakia (UN Doc A/C.6/53/SR.22, para 32$)$.

151 Mexico (UN Doc A/C.6/53/SR.16, para 18); Uruguay (UN Doc A/C.6/53/SR.16, para 97); Spain (UN Doc A/C.6/53/SR.18, para 46); Slovakia (UN Doc A/C.6/53/SR.22, para 32). For a view that stresses the close connection between diplomatic protection and human rights, see Chile (UN Doc A/C.6/53/SR.14, para 29).

$15^{2}$ ILC, 'Draft articles on diplomatic protection' (n 149) 27 (commentary to article 1, paras 3-4).

153 ILC, 'Survey of International Law in Relation to the Work of Codification of the International Law Commission' (n 65) 15 at para 20. 
apt example of evolutionary interpretation of an international document "of continuing duration". One knows well that the Commission of 2018 operates within a substantially changed landscape as compared to the Commission of 1948. The international community, composed of almost 200 States and over seven billion human beings, is destined to undergo a constant change and evolution that inevitably affects the contours and (even) structures of international law. The International Law Commission, whose statute has remained almost unchanged, has no alternative but to resort to an evolutionary interpretation of its constituent instrument, including articulating its understanding of the Commission's core function and role in an evolutionary manner. In so doing, the Commission should make every effort to bring itself up to the honourable task of meeting the normative expectations of the international community as the body for the progressive development and codification of international law.

\section{Concluding Remarks}

In this contribution, I conducted an overview of the historical evolution of the concept of codification of international law, beginning with Bentham's proposals, leading up to the adoption of the Commission's statute. The overview drew our attention to, among others, the two questions that maintained their relevance throughout the subsequent discussions of codification of international law, i.e. the distinction between codification and legislation (or development) of international law and the diplomatic, or political, character of the work involved. Ideas or concepts having a long pedigree such as codification of international law inevitably end up being composed of different layers of meanings. This was shown by the short analysis of the discussion at the inaugural session of the International Law Commission where members held widely diverging conceptions of codification of international law. The murky state of affairs in 1949, in particular the distinction between progressive development and codification of international law, did not disappear for some time. But the question was addressed by the subsequent practice of the Commission; the two methods have been largely merged into one. This was achieved without amending the relevant provisions of the statute.

In this paper, I ventured a taxonomy of codification discussed or carried out by the Commission. This taxonomy, composed of (i) mega- or total codification, (ii) foundational or architectural codification, (iii) thematic codification, and (iv) complementary or annotative codification, was conducted for prescriptive as well as descriptive purposes. Based on that taxonomy, I hazarded a 
few suggestions for the strengthening of the role and status of the International Law Commission. The main suggestion is to redress the balance between various categories of codification, particularly in favour of what I termed foundational or architectural codification.

On its seventieth anniversary, the Commission is fully entitled to look back on the past seven decades with a sense of pride. At the same time, this anniversary should provide an opportunity to take stock of its activities up to now and devise some ways to live up to its task mandated by the international community. Such an exercise is necessary in light of some concerns raised on the future role and relevance of the Commission. ${ }^{154}$

In so doing, the Commission may want to remind itself that, despite the inherently diplomatic and political character of codification of international law, the Commission is composed of "persons of recognized competence in international law" serving in individual capacities (even though the individual capacities are not expressly provided for in the statute). In charting the choppy waters through which it has to navigate in the coming decades, the Commission can draw some inspiration and courage from the document that constituted the basis of discussion at the inaugural session of the International Law Commission. In discussing the value of drafts to be produced by the Commission, the author of the document stated as follows:

They would exercise influence partly as statements of the existing law and partly as pronouncements of what is a rational and desirable development of the law on the subject. They would be at least in the category of writings of the most qualified publicists, referred to in Article 38 of the Statute of the International Court of Justice as a subsidiary source of law to be applied by the Court. Most probably their authority would be considerably higher. For they will be the product not only of scholarly research, individual and collective, aided by the active co-operation of Governments, of national and international scientific bodies, and the resources of the United Nations. They will be the result of the deliberation and of the approval of the International Law Commission. Outside the

154 It was not that long ago that a former member of the Commission mentioned "oftenexpressed concerns about the relevance of the ILC as an institution for the progressive development of international law and its codification". McRae (n 3$)$ 76. For an exceptionally candid discussion of the same question by a current member of the Commission, see the statement by Professor Murase speaking as a member of the Japanese delegation. UN Doc A/C.6/66/SR.18, para $5^{8}$ ("In recent years some critics, particularly in academic circles, had been saying that the Commission was useless and should be disbanded.") 
sphere of international judicial settlement they will be of considerable potency in shaping scientific opinion and the practice of Governments. ${ }^{155}$

155 ILC, 'Survey of International Law in Relation to the Work of Codification of the International Law Commission' (n 65) 16 at para 20. The author is understood to have been Hersch Lauterpacht, who himself became a member of the Commission in 1952, until his election to the International Court of Justice in 1954. 